Article

\title{
Shedding Light on Eco-Innovation in Tourism: A Critical Analysis
}

\author{
Maria-del-Mar Alonso-Almeida ${ }^{1, *}$, Alfredo Rocafort ${ }^{2}$ and Fernando Borrajo ${ }^{1}$ \\ 1 Business Organization Department, Autonomous University of Madrid, Madrid 28049, Spain; \\ fernando.borrajo@uam.es \\ 2 Accountability Department, University of Barcelona, Barcelona 08007, Spain; ubbusiness@ub.edu \\ * Correspondence: mar.alonso@uam.es; Tel.: +34-914-974-000
}

Academic Editor: Marc A. Rosen

Received: 9 September 2016; Accepted: 29 November 2016; Published: 3 December 2016

\begin{abstract}
The recent global increase in the competitiveness of tourism has made the implementation of eco-innovations a differentiating element among both the destinations and companies in the sector, with quality management and contribution to sustainable development being increasingly valued. However, the eco-innovations that have been developed and implemented in tourist industries have rarely been studied. In this study, the eco-innovations that have been developed and implemented by 57 tourism businesses worldwide are analysed. The identified eco-innovations are classified by using different qualitative methodologies. The obtained results shed light on the limited development of eco-innovations in the tourism industry and the industry focuses mainly on product eco-innovations. Several examples by the tourist sub-industry and types of eco-innovation are analysed. Furthermore, this study provides practical information about measures that both businesses and governmental organisations can adopt to promote eco-innovation in the sector.
\end{abstract}

Keywords: eco-innovation; qualitative methodology; content analysis; innovation; ecology; Delphi analysis; ecotourism; hospitality

\section{Introduction}

Tourism is the primary services industry that generates employment and economic development. It is so important that, according to the World Tourism Organization [1], "tourism contributes 5\% of the world's GDP. It accounts for $6 \%$ of the world's exports in services, being the fourth largest export sector after fuels, chemicals, and automotive products. Tourism is responsible for 235 million jobs, or one in every 12 jobs worldwide".

The recent global increase in competitiveness has made the implementation of innovations a differentiating element among both the destinations and companies in the sector, with quality management and contribution to sustainable development being increasingly valued [2,3]. This view, on the one hand, notes that at the strategic level, innovation in the tourism sector is closely related to the concern for differentiation, but, on the other hand, indicates that these innovations are considering environmental issues to a greater extent, as evidenced by the growing number of environmental management system certifications that hotel establishments display. Therefore, although any type of innovation in business management can translate into a competitive advantage for the agents involved, eco-innovation will not only benefit both the company and the community in which eco-innovation is performed, but also have a three-fold positive effect on the company, the community as a whole, and the environment [4], while creating distinctive personalised competencies that are difficult to imitate, at least in the short term. Thus, a definition of eco-innovation from previous tourism research is "the creation of novel and competitively priced goods, processes, systems, services, and procedures designed to satisfy human needs and provide a better quality of life for everyone with a whole-life-cycle 
minimal use of natural resources (materials including energy and surface area) per unit output, and a minimal release of toxic substances" [5,6].

Thus, insufficient commitment to the environment and less-developed innovative capabilities by businesses in this field will mean, in the medium to long term, a great loss in market competitiveness because the near future will be governed by those who follow an eco-efficient model and strategy that adapts and stays ahead of the environment in which they perform their activities. Because a reduction in environmental impact, increased environmental conservation, and local development are vital for tourism and the development of its activities, it seems more than logical that the presence of eco-innovations in the tourism sector will become increasingly important in the near future. The opposite can only lead the sector to a loss of competitiveness, lowered tourism prices, and a widespread loss of wealth and employment creation [7]. However, Miret et al. [8] (p. 16) noted that "eco-innovation appears to be one of the great challenges for the tourist industry today" because although some companies have adopted environmental management measures, these measures have been basic, as different studies have highlighted [9].

Because of the limited research on eco-innovations in the tourism sector, this exploratory study aims to examine the development of eco-innovations. To achieve that end, two main goals are proposed. First, this study examines the development and typology of eco-innovations among tourism companies worldwide. A total of 57 tourism companies are analysed using several qualitative methods to ensure reliability. Second, to examine eco-innovation knowledge, the contingent theory umbrella is used. According to the contingency theory, each company is viewed as a unique entity because of each feature distinguishing characteristic, denominated dimensions or factors. These dimensions, some external and others company-specific, affect its organizational behavior [3,4]. The most relevant factors in tourism are type of tourist industry, size and location of headquarters [7]. Thus, several highly innovative aspects that have not been previously studied in the tourism sector are addressed in a holistic manner.

Below, a literature review is performed, the methodology is presented, the results are analysed, and some conclusions and futures lines of research are described.

\section{Literature Review}

\subsection{Concept of Eco-Innovation}

Mossalanejad [10] (p. 396) defines the concept of eco-innovation as "a new series of processes and products that should increase value to customers and businesses but with a significant reduction in the impact on the environment and pollution". However, at present, there is still no agreement on the definition of the concept of eco-innovation, and it continues to be shaped [8], implying an initial development stage in this field of research, which is greater still when focusing on the tourism sector, given the lack of studies related to this topic $[5,6]$.

Moreover, "eco-innovation is the introduction of any new or significantly improved product (good or service), process, organisational change or marketing solution that reduces the use of natural resources (including materials, energy, water, and land) and that decreases the release of harmful substances across the entire life-cycle" [11] (p. 53). Clearly, eco-innovation is multidimensional. Additionally, eco-innovations are not exclusively linked to individual company implementations but occupy a very important place in ecological business models. This not only creates environmentally friendly products but also results in a more sustainable economy [12]. Finally, eco-innovation can contribute to the establishment of business and social networks, increased social capital, business cooperation, and the creation of new relationships between the public and private sectors.

For those reasons, Hojnik and Ruzzier [13] asserted that all definitions of eco-innovation agree with the increasing value of environment and reflect two effects of eco-innovations: a reduction of adverse effects on the environment and a more environmentally friendly use of resources. 
Thus, eco-innovation seeks to balance business development and productivity with ecological concerns and a respect for the environment so natural resources can be conserved and efficiently used by the tourism sector. As a result, eco-innovation directly influences both economic and social growth through the care for the environment, the maintenance and creation of new jobs, and the acquisition of new skills, new products, and new businesses, all of which positively influence the economy.

However, the eco-innovation has its own peculiarities. First, it can adopt different types of management, and second, it requires an interdisciplinary approach.

\subsection{Evolution of Eco-Innovation}

To understand eco-innovation, it is necessary to understand its current state. Previous research on sustainability in the tourism sector originated two decades ago as an analysis of the adoption of environmentally friendly practices among other works [9,14-20] and its economic impact [21]. Sustainability impacts the economy in three ways: (1) it has a direct effect through energy savings; (2) it has an indirect effect because an environmentally friendly image creates a competitive advantage; and (3) the business gains the advantage of being positioned as a green company [14-19,22-28]. To a lesser extent, previous research has found that there is a social impact $[2,11]$ and an impact on the acquisition of unique capabilities $[2,29,30]$.

However, the research in eco-innovation is more recent; therefore, it is at an initial or embryonic stage. As is the case in other fields of study, it began in the manufacturing sector. In particular, the creation and adoption of eco-innovations have been analysed in this sector, and a series of triggers for their development have been identified. These triggers, such as investment in Research \& Development \& Innovation and the export capacity of an innovation [31-34], have little place in the services sector. However, other triggers, such as the possession or size of a critical mass of resources and capabilities, the domain of certain technological capabilities, and the existence of organisational characteristics that are specific to each firm [31,32,34], can belong to all types of sectors. Regardless, it seems that there is a consensus that indicates that environmental regulation and market mechanisms are the main triggers for the creation, development, and dissemination of eco-innovations [34-37]. This consensus changes on the basis of the limited research that has been conducted in the services sector, which suggests that more drivers come from the environment in which the company develops its activity than from within the company itself $[36,37]$. Thus, later research noted that internal factors could push more than external ones because companies have little or no control over external factors [38].

Additionally, barriers to the development of eco-innovations in the services sector have been identified, including a lack of absorptive capacity in processes, trained human resources, business maturity, and technological capabilities [39-41].

In addition, previous research has stressed the importance of the wording of eco-innovation taxonomies [38,41,42]. The research primarily follows the typology of innovations proposed in the Oslo Manual, although some variants and extensions have been added [43-45]. The Oslo Manual defines innovation as "the implementation of a new or significantly improved product (good or service), or process, a new marketing method, or a new organisational method in business practices, workplace organisation, or external relations" [46] (p. 9). Based on the Oslo Manual, five types of business innovations are recognized: product-related, process-related, technological, marketing-related, and organisational.

Finally, although to a lesser extent given the novelty of the subject, studies have been conducted on the impact that eco-innovations have on the performance of the businesses that implement them, ultimately concluding that their influence is positive [47], though to varying degrees, depending on the type of eco-innovation established [41,48].

Research on tourism is even more limited. Topics that have been studied include the role of eco-innovations in the choice of tourism establishments, such as restaurants [49], the types of eco-innovations adopted by restaurants $[17,50]$ and by hotels $[17,51]$, and the importance of using eco-innovations in the physical environment design of restaurants to generate an innovative 
atmosphere [52]. Importantly, eco-innovations include numerous activities that affect businesses and tourist destinations in areas such as energy; recycling; water; new construction development; interior design; engineering projects; responses to external environmental degradation; new products, processes, and business models; adaptations of products and existing materials; new materials; the use of eco-biological products; spatial planning; and the wellness industry, which, in some regions, may also include the development and transformation of organic products, eco-tourism, and therapeutic tourism. If we consider that each eco-innovation involves the combination of factors with numerous activities, we can conclude that the generation, development, adoption, and dissemination of eco-innovations are different and far more complex than are those of other innovations [53] because each eco-innovation comprises several innovations.

\section{Methodology and Sample}

As aforementioned, based on the definition of innovation in the Oslo Manual, five types of business innovations are recognized: product-related, process-related, technological, marketing-related, and organisational [46]. As with previous studies [34], the classifications used in this paper begin with the identification of eco-innovations in the tourism sector.

To search for and describe eco-innovations in the tourism sector, a review of the companies that provided their reports to the Global Reporting Initiative (GRI) in 2014 was performed. The GRI database was used for a number of reasons: (1) it is the most widely used worldwide standard for sustainability reporting; (2) GRI represents the best option available for SR because it is based on foundations that consider economic, environmental and social dimensions; (3) GRI presents a harmonized, standardized, understandable and objective report for all firms worldwide; and (4) the GRI is, after the ISO14001 standard, the most influential standard regarding social responsibility [54-56].

The first step was to review the list of industries in which the companies were categorized; these included hospitality, restaurants, leisure, travel, and cruises in the Leisure and Hospitality categories as well as the Foods and Beverages categories. A total of 57 reports were downloaded in English. They formed the full sample of these categories. Thus, the total population was gathered. These reports have proven to be a relevant source of information for understanding organisational behaviour in terms of sustainability and identifying critical issues in this context [54].

Second, different qualitative methods were used in a "blended" manner to identify and classify eco-innovations and thereby obtain an overview of what is occurring in the tourism sector. To that end, the content analysis method and Delphi analysis were used.

Information from each report was analysed by using the content analysis method to identify the eco-innovations adopted by tourism companies. The process was followed both to select the keywords for the eco-innovation search and to confirm these eco-innovations, and their typology was determined through Delphi analysis. The use of these two methodologies allowed us to eliminate bias and helped validate the results. The process is shown in detail in Figure 1.

The experts were academics whose research was in innovation, and practitioners in the tourism industry. Both profiles are the most suitable given their knowledge-in the former case, for their knowledge on the topic-innovation - and the others for their knowledge on business-tourism. A total of 15 experts participated in the Delphi analysis. This number is enough to guarantee validity. The key words agreed upon were: eco-innovation, environmental innovation, innovation driver; environmental sustainability, adoption of environmental innovation and eco-collaboration. A total of 49 eco-innovations were identified and analysed from the reports of 28 different tourism companies. The remaining reports did not contain any eco-innovations. Table 1 shows the main characteristics of the sample.

Thus, only $49.1 \%$ of the population has deployed some eco-innovations. As shown in Table 1, most of the tourism companies are large companies, and there is a clear under-representation of SMEs in the sample, as noted in previous research [57]. Europe is the primary location where tourism companies have developed eco-innovations. This figure is in line with previous research in sustainability, which highlighted the relevant engagement of Europe in sustainability [56,57]. 


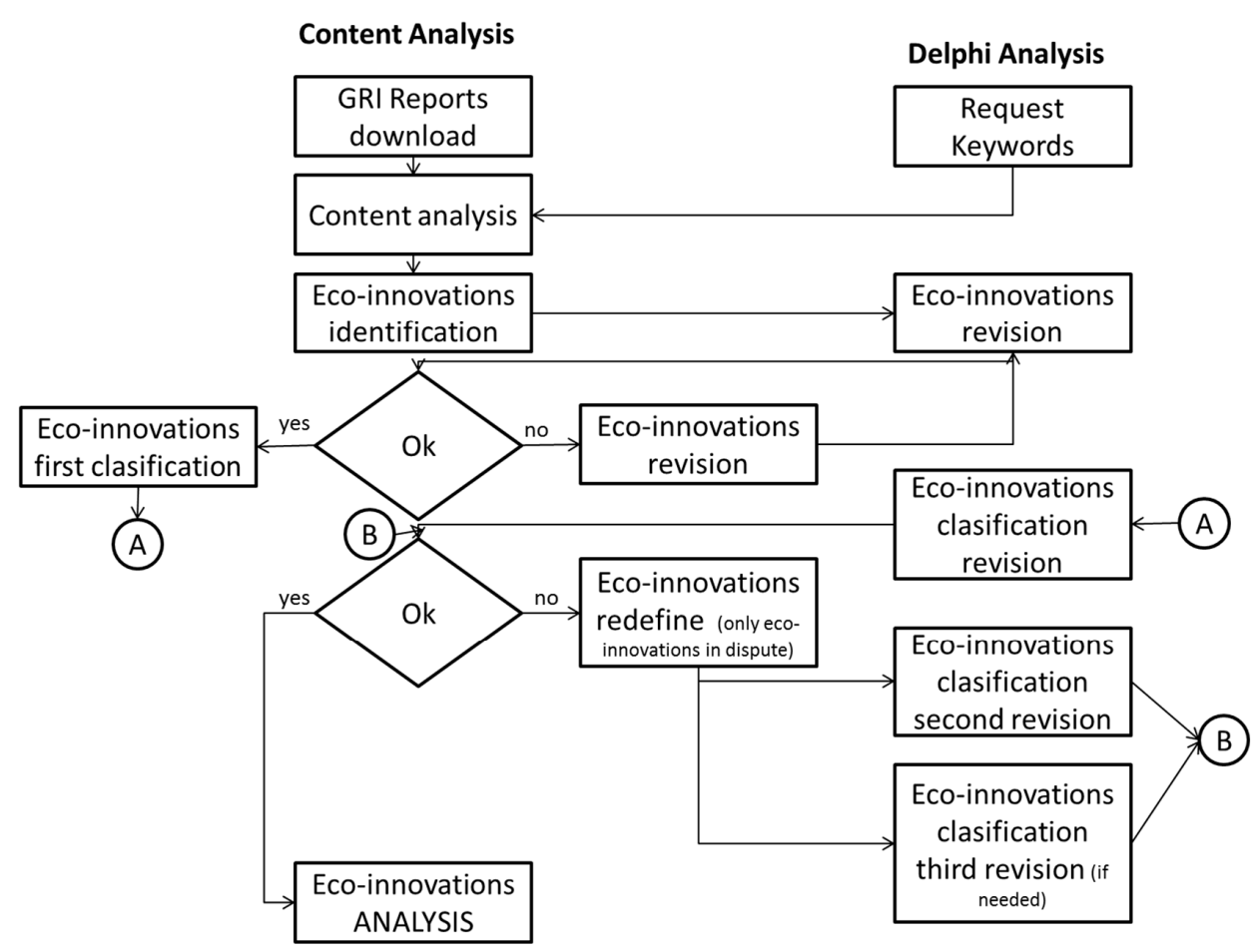

Figure 1. Information analysis method.

Table 1. Details of the sample.

\begin{tabular}{ccc}
\hline Dimension & Sub-Dimension & Number \\
\hline \multirow{4}{*}{ Place } & Europe & 12 \\
& North America & 7 \\
& Asia & 6 \\
& Africa & 2 \\
& Latin America & 1 \\
\hline \multirow{3}{*}{ Size } & MNE & 12 \\
& Large & 13 \\
& SME & 3 \\
\hline \multirow{3}{*}{ Industry } & Hospitality & 8 \\
& Restaurants & 11 \\
& Travel & 2 \\
& Leisure & 2 \\
& Cruises & 5 \\
\hline
\end{tabular}

The Delphi analysis "consists in collecting the "raw" opinion of experts at a time $t$ on a series of questions and to confront these opinions with those collected through a second investigation, where each expert can review his/her judgement knowing the average opinion of the first phase. This two-stage procedure is then able to exhibit deviant behaviours of the first round and more consensual futures of the second round. Moreover, the inquiry includes variables expressing the nature of the expert such as his/her age, knowledge, and institutional membership" [58] (p. 422). This analysis included two steps. First, keywords were identified to find eco-innovations in the content analysis. Second, the eco-innovations found in the content analysis were revised to confirm the classification of the eco-innovations.

A content analysis was performed as follows. First, the reports were searched for key words. Second, when key words were found, a detailed revision of the text was completed to identify the eco-innovations. Finally, the eco-innovations were sent to experts to confirm that they were eco-innovations and determine their classification. 


\section{Results and Discussion}

The results are shown below. Table 2 shows the global eco-innovations that were identified and classified and emphasises the most relevant adoption factors such as company size and geographical area. These factors were identified in previous studies [56].

Table 2. Global results.

\begin{tabular}{|c|c|c|c|c|c|}
\hline Eco-Innovation & Product-Related & Process-Related & Technological & Marketing-Related & Organisational \\
\hline Place & $\begin{array}{c}36 \% \text { Europe } \\
27 \% \text { Asia } \\
23 \% \text { North America } \\
9 \% \text { Africa } \\
5 \% \text { Latin America }\end{array}$ & $\begin{array}{c}50 \% \text { North America } \\
33 \% \text { Europe } \\
17 \% \text { Asia }\end{array}$ & $\begin{array}{c}45 \% \text { Europe } \\
36 \% \text { North America } \\
9 \% \text { Asia } \\
9 \% \text { Africa }\end{array}$ & $\begin{array}{c}66 \% \text { North America } \\
44 \% \text { Europe }\end{array}$ & 100\% Europe \\
\hline Size & $\begin{array}{l}55 \% \text { MNE } \\
36 \% \text { Large } \\
9 \% \text { SME }\end{array}$ & $\begin{array}{l}58 \% \mathrm{MNE} \\
42 \% \text { Large }\end{array}$ & $\begin{array}{l}\text { 80\% MNE } \\
20 \% \text { Large }\end{array}$ & $100 \% \mathrm{MNE}$ & $100 \% \mathrm{MNE}$ \\
\hline Industry & $\begin{array}{c}36 \% \text { Hospitality } \\
32 \% \text { Restaurants } \\
\text { 14\% Travel } \\
\text { 14\% Leisure } \\
5 \% \text { Cruises }\end{array}$ & $\begin{array}{c}58 \% \text { Restaurants } \\
25 \% \text { Cruises } \\
8 \% \text { Hospitality } \\
8 \% \text { Travel }\end{array}$ & $\begin{array}{c}55 \% \text { Restaurants } \\
27 \% \text { Cruises } \\
9 \% \text { Hospitality } \\
9 \% \text { Travel }\end{array}$ & $\begin{array}{l}67 \% \text { Hospitality } \\
33 \% \text { Restaurant }\end{array}$ & $\begin{array}{c}100 \% \\
\text { Hospitality }\end{array}$ \\
\hline
\end{tabular}

$\%$ of companies by type of eco innovation based on their primary characteristics.

Previous research on sustainability in the tourism sector found that, for various reasons, the hospitality industry and restaurants were making substantial efforts to incorporate environmental measures [9,14-21,28]. Therefore, the results suggest that these industries are pioneers in the development and adoption of eco-innovations. Although the cruise industry is included in the analysis of eco-innovations, it has yet to be studied. Thus, it will be necessary to go into detail in the future to confirm this finding. Similarly, the travel industry seems to be developing eco-innovations that are mainly oriented towards travel products and their development, although to a lesser extent.

Regarding geographical distribution, Europe continues to be a pioneer in the adoption and development of eco-innovations [56,57] in the tourism sector. This finding can be explained by several reasons. One general reason that is associated with all sectors and industries is the sustainability strategy that European authorities are encouraging, with the objective of reaching the full development of a circular economy by 2050. There are also other specific reasons, such as the importance of tourism in Europe and the need to conserve natural and heritage resources.

Finally, regarding company size, larger companies are increasingly developing eco-innovations. As is found in other sectors, size is a trigger that provides a critical mass of resources and capabilities as well as access to technological capabilities, which is limited in smaller companies $[34,53]$. However, this finding requires a more detailed analysis because many small businesses are developing very active strategies and behaviours in the adoption of various types of sustainable practices $[2,7,18,20]$.

The results found by industry are analysed in Table 3.

As shown in Table 3, the only type of eco-innovation that has been adopted and developed to some extent by all tourism sectors is product-related eco-innovation. These eco-innovations primarily respond to the development of products for certain market niches or the deployment of differentiation or focus strategies and are generally used to pursue an improved competitive position $[2,7,17,18,20,58]$.

Second, process-related and technological eco-innovations stand out. These are developed by most tourism industries but are very focused in two geographical areas, i.e., Europe and North America, with almost a total absence in other geographical regions. This finding differs from previous research $[55,56]$ in that North America is shown to be the second largest geographical area in terms of the development and adoption of eco-innovations in the tourism industry, whereas the role of Asia is limited. Therefore, it is also necessary to investigate this area further. 
Finally, both marketing-related and organisational eco-innovations are only in their early development, thus corroborating the fact that eco-innovation in tourist industries as a whole is in its infancy.

Table 3. Industry results.

\begin{tabular}{|c|c|c|c|c|c|}
\hline \multirow{2}{*}{$\begin{array}{c}\text { Industry } \\
\text { Hospitality }\end{array}$} & \multicolumn{5}{|c|}{ Eco-Innovation Typology } \\
\hline & Product-Related & Process-Related & Technological & Marketing-Related & Organisational \\
\hline Place & $\begin{array}{l}50 \% \text { Asia } \\
40 \% \text { Europe } \\
10 \% \text { Africa }\end{array}$ & $100 \%$ Europe & $100 \%$ Europe & $100 \%$ Europe & $100 \%$ Europe \\
\hline Size & $\begin{array}{l}40 \% \text { MNE } \\
60 \% \text { Large }\end{array}$ & $100 \%$ Large & $100 \% \mathrm{MNE}$ & $100 \% \mathrm{MNE}$ & $100 \% \mathrm{MNE}$ \\
\hline Restaurant & Product-Related & Process-Related & Technological & Marketing-Related & Organisational \\
\hline Place & $\begin{array}{c}60 \% \text { N. America } \\
18 \% \text { Europe } \\
11 \% \text { Asia } \\
11 \% \text { Latin America }\end{array}$ & $\begin{array}{c}60 \% \text { N. America } \\
\text { 30\% Europe } \\
10 \% \text { Asia }\end{array}$ & $\begin{array}{c}50 \% \text { N. America } \\
50 \% \text { Europe }\end{array}$ & $100 \%$ N. America & Not found \\
\hline Size & $100 \% \mathrm{MNE}$ & $\begin{array}{l}60 \% \text { MNE } \\
40 \% \text { Large }\end{array}$ & $\begin{array}{l}80 \% \text { MNE } \\
20 \% \text { Large }\end{array}$ & $100 \% \mathrm{MNE}$ & Not found \\
\hline Cruises & Product-Related & Process-Related & Technological & Marketing-Related & Organisational \\
\hline Place & $100 \%$ Europe & $\begin{array}{c}67 \% \text { N. America } \\
33 \% \text { Europe }\end{array}$ & $\begin{array}{l}50 \% \text { N. America } \\
50 \% \text { Europe }\end{array}$ & Not found & Not found \\
\hline Size & $100 \%$ Large & $\begin{array}{l}\text { 67\% MNE } \\
33 \% \text { Large }\end{array}$ & $\begin{array}{l}80 \% \text { MNE } \\
20 \% \text { Large }\end{array}$ & Not found & Not found \\
\hline Travel & Product-Related & Process-Related & Technological & Marketing-Related & Organisational \\
\hline Place & $\begin{array}{c}\text { 67\% Europe } \\
33 \% \text { Asia }\end{array}$ & $100 \%$ Europe & $100 \%$ Europe & Not found & Not found \\
\hline Size & $\begin{array}{l}34 \% \text { MNE } \\
33 \% \text { Large } \\
33 \% \text { SME }\end{array}$ & $100 \%$ Large & $100 \%$ Large & Not found & Not found \\
\hline Leisure & Product-Related & Process-Related & Technological & Marketing-Related & Organisational \\
\hline Place & $\begin{array}{c}50 \% \text { Asia } \\
40 \% \text { Europe } \\
10 \% \text { Africa }\end{array}$ & Not found & Not found & Not found & Not found \\
\hline Size & $\begin{array}{l}34 \% \text { MNE } \\
33 \% \text { Large } \\
33 \% \text { SME }\end{array}$ & Not found & Not found & Not found & Not found \\
\hline
\end{tabular}

In Table 4, the main eco-innovations by sub-industry and eco-innovation are shown. As can be seen, the use of different alternative energy sources is one of the main eco-innovations adopted such as solar panels and geothermal energy. Water storage and reuse is also another frequent eco-innovation developed. Hotels and restaurants are engaged with healthy food, growing their own vegetable gardens and offering them to their customers. These eco-innovations stress the importance in the tourism industry to improve internal efficiency and seek ways to be differentiated from competitors.

In short, the development and adoption of eco-innovations in tourism are at an early stage, although the development of product-related eco-innovations ranks first, followed by process-related and technological eco-innovations. However, the development of marketing-related and organisational eco-innovations is almost non-existent. Because these results are a first approach to the subject, they must be interpreted with caution and confirmed with more research in the near future. 
Table 4. Samples of eco-innovations adopted by type and industry.

\begin{tabular}{|c|c|c|c|c|c|}
\hline Sub-Industry & Product-Related & Process-Related & Technological & Marketing-Related & Organisational \\
\hline Hospitality & $\begin{array}{l}\text { Eco-design. } \\
\text { Biodegradable } \\
\text { amenities. } \\
\text { Urban vegetable } \\
\text { garden on the roof. }\end{array}$ & $\begin{array}{l}\text { Measurement of the } \\
\text { carbon footprint. } \\
\text { Storage of rainwater } \\
\text { or groundwater for } \\
\text { irrigation. }\end{array}$ & $\begin{array}{l}\text { Geothermal energy. } \\
\text { Electrical vehicles } \\
\text { for inside } \\
\text { transport. }\end{array}$ & $\begin{array}{l}\text { Ecological shops } \\
\text { with geothermal } \\
\text { plants. }\end{array}$ & $\begin{array}{l}\text { Eco-innovation } \\
\text { education. }\end{array}$ \\
\hline Restaurants & $\begin{array}{l}\text { Biodegradable } \\
\text { cutlery. } \\
\text { Organic products. } \\
\text { Vegetable garden. }\end{array}$ & $\begin{array}{l}\text { Reuse of rainwater } \\
\text { for toilets. }\end{array}$ & $\begin{array}{l}\text { Paper elimination. } \\
\text { Solar panels use. }\end{array}$ & $\begin{array}{l}\text { Discounts for those } \\
\text { who have their own } \\
\text { containers to eat }\end{array}$ & \\
\hline Cruises & $\begin{array}{l}\text { Pioneer system of } \\
\text { temperature recovery } \\
\text { for transformation } \\
\text { into energy, steam } \\
\text { and water for use. }\end{array}$ & $\begin{array}{l}\text { Wastewater } \\
\text { purification System } \\
\text { process for reuse. }\end{array}$ & $\begin{array}{l}\text { Technology for air } \\
\text { lubrication system, } \\
\text { creating bubbles } \\
\text { that reduce friction } \\
\text { with water. }\end{array}$ & & \\
\hline Travel & Eco-routes. & $\begin{array}{l}\text { Eco-energy } \\
\text { generation. } \\
\text { Measurement of the } \\
\text { carbon footprint. }\end{array}$ & $\begin{array}{l}\text { Software energy } \\
\text { control systems. }\end{array}$ & & \\
\hline Leisure & $\begin{array}{l}\text { Use of an alternative } \\
\text { ecological surface to } \\
\text { the sand that does } \\
\text { not require irrigation } \\
\text { or dust. }\end{array}$ & & & & \\
\hline
\end{tabular}

\section{Conclusions}

The European Union [59] states that the objective of eco-innovation is "to become the most competitive and dynamic knowledge-based economy, capable of sustainable economic growth with more and better jobs and greater social cohesion, complying with environmental commitments currently claimed by society and by international communities and conventions such as the Kyoto Protocol". Therefore, eco-innovation has a fundamental and clearly defined objective: to promote a sustainable future that is conditioned by and for the balance between social, economic, and environmental concerns.

Eco-innovations also encourage creativity. Thus, examples of both technological and non-technological eco-innovations have been identified, resulting in original and creative changes in processes, factors that should be maintained in the entrepreneurial mind-set and translated into market demand.

Eco-innovations in the tourism sector mainly involve the implementation and adaptation of products that have been applied to the needs of a market that demands novelty. Simultaneously, however, the market requires traditional customer satisfaction and that changes be well received by the latter. Thus, it seems advisable to break through the specific fear of change that is found in traditional industries such as tourism and to bet on a stronger presence of product eco-innovations in the form of new goods and services that are mainly focused on ecological consumption because it is a new market and thus offers a large gap for new innovative proposals.

Technological and process-related eco-innovations essentially stem from other industries and have been successfully adopted by this sector [4]. In this sense, Hjalager [60] provides a systematic and analytical compilation of 100 innovations that were not created specifically for tourism. Nonetheless, tourism has been deeply affected, and the contribution of innovations to its development, as we know it today, has been significant. Among other resulting impacts are the increase in mobility, the development of new travel experiences, increases in the productivity and profitability of tourism companies, business growth, and the opening of new destinations. Thus, a deeper understanding of eco-innovations in other sectors seems necessary to transfer this knowledge to the tourism sector. Therefore, it is recommended that the sector and relevant international and supranational agencies 
strategically monitor the eco-innovations that are made in other sectors and their potential applications to the tourism sector.

Finally, as shown above, eco-innovation in the tourism sector still has great potential in the near future. For practitioners, this research confirms the importance of eco-innovations for restaurants and hotels in areas such as energy; recycling; water; new construction development; interior design; engineering projects; responses to external environmental degradation; new products, processes, and business models; adaptations of products and existing materials; new materials; the use of eco-biological products; spatial planning; and the wellness industry, which, in some regions, may include the development and transformation of organic products, eco-tourism, and therapeutic tourism. Additionally, it confirms the urgent need to engage in eco-innovation adoption and development in all tourism sub-sectors and typologies.

For academics, it is a line of research that is in its infancy and is thus fully under construction. It opens a number of possibilities to investigate in the short term, such as taking a closer look at the previously indicated aspects of eco-innovation typologies and performing in-depth case studies that enable the identification of better practices and the implementation of a road map for small businesses that lack the resources and knowledge of large companies. In addition, in-depth analyses using case studies of companies will allow us to overcome the limitations of using secondary data sources. In the long term, eco-innovation should be analysed in the context of circular economies and the contribution of tourism to the circular economy.

The main limitation of this paper is that its generalisation is limited because the sample is small. However, this paper does not pursue generalisation because the knowledge of this topic is still very scarce. Thus, this paper is a first step to shed light on eco-innovation in tourism.

Acknowledgments: The authors are extremely grateful to the Sustainability journal editorial team and reviewers who provided valuable comments for improving the quality of this article.

Author Contributions: Maria-del-Mar Alonso-Almeida conceived and designed the research. All of the co-authors performed the research, analysed the data, and wrote and revised the paper.

Conflicts of Interest: The authors declare no conflict of interest.

\section{References}

1. World Tourism Organization. Tourism and Poverty Alleviation. 2015. Available online: http://step.unwto. org/content/tourism-and-poverty-alleviation-1 (accessed on 1 September 2016).

2. Bagur-Femenias, L.; Llach, J.; Alonso-Almeida, M.M. Is the adoption of environmental practices a strategical decision for small service companies? An empirical approach. Manag. Decis. 2013, 51, 41-62. [CrossRef]

3. Llach, J.; Alonso-Almeida, M.M.; García-Castellví, A.; Bagur-Femenias, L. A fresh approach to context influence, development and performance in environmental management. Bus. Strategy Environ. 2015, 24, 855-872. [CrossRef]

4. Chen, S.H. The influencing factors of enterprise sustainable innovation: An empirical study. Sustainability 2016, 8, 425. [CrossRef]

5. García-Pozo, A.; Sánchez-Ollero, J.L.; Marchante-Lara, M. Eco-innovation and management: An empirical analysis of environmental good practices and labour productivity in the Spanish hotel industry. Innovation 2015, 17, 58-68. [CrossRef]

6. García-Pozo, A.; Sánchez-Ollero, J.L.; Ons-Cappa, M. ECO-innovation and economic crisis: A comparative analysis of environmental good practices and labour productivity in the Spanish hotel industry. J. Clean. Prod. 2016, 138, 131-138. [CrossRef]

7. Hong, S.W.C. Competitiveness in the Tourism Sector: A Comprehensive Approach from Economic and Management Points; Springer Science \& Business Media: Taipei, Taiwan, 2008.

8. Miret, L.; Segarra, M.; Peiró, A. ¿Cómo medimos la Ecoinnovación? Análisis de indicadores en el Sector Turístico. TEC Manag. 2011, 5, 15-25.

9. Alonso-Almeida, M.M.; Bagur-Femenias, L.; Llach, J.; Perramon, J. Sustainability in small tourist businesses: The link between initiatives and performance. Curr. Issues Tour. 2015. [CrossRef] 
10. Mossalanejad, A. The role of economic policy and environment in sustainable development. Int. J. Environ. Res. 2011, 5, 395-402.

11. Escuela de Organización de Empresas. Sectores de la Nueva Economía 2020. Innovación Turística; Fundación EOI: Madrid, Spain, 2015.

12. The Organisation for Economic Co-Operation and Development (OECD). Green Innovation in Tourism Services; OECD Tourism Papers, 2013/01; OECD Publishing: Paris, France, 2013.

13. Hojnik, J.; Ruzzier, M. What drives eco-innovation? A review of an emerging literature. Environ. Innov. Soc. Trans. 2016, 19, 31-41. [CrossRef]

14. Alvarez-Gil, M.J.; Burgos-Jimenez, J.; Cespedes-Lorente, J.J. An analysis of environmental management, organizational context and performance of Spanish hotels. Omega 2001, 29, 457-471. [CrossRef]

15. Carmona-Moreno, E.; Cespedes-Lorente, J.; de Burgos-Jimenez, J. Environmental strategies in Spanish hotels: Contextual factors and performance. Serv. Ind. J. 2004, 24, 101-130. [CrossRef]

16. Pereira-Moliner, J.; Claver-Cortés, E.; Molina-Azorín, J.P.; Tarí, J.J. Quality management, environmental management and firm performance: Direct and mediating effects in the hotel industry. J. Clean. Prod. 2012, 37, 82-92. [CrossRef]

17. Alonso-Almeida, M.M. Water and waste management in the Moroccan tourism industry: The case of three women entrepreneurs. Women Stud. Int. Forum 2012, 35, 343-353. [CrossRef]

18. Llach, J.; Perramon, J.; Alonso-Almeida, M.M.; Bagur-Femenias, L. Joint impact of quality and environmental practices on firm performance in small service businesses: An empirical study of restaurants. J. Clean. Prod. 2013, 44, 96-104. [CrossRef]

19. Best, M.N.; Thapa, B. Motives, facilitators and constraints of environmental management in the Caribbean accommodations sector. J. Clean. Prod. 2013, 52, 165-175. [CrossRef]

20. Perramon, J.; Alonso-Almeida, M.M.; Llach, J.; Bagur-Femenías, L. Green practices in restaurants: Impact on firm performance. Oper. Manag. Res. 2014, 7, 2-12. [CrossRef]

21. Molina-Azorín, J.F.; Claver-Cortes, E.; Pereira-Moliner, J.; Tarí, J.J. Environmental practices and firm performance: An empirical analysis in the Spanish hotel industry. J. Clean. Prod. 2009, 17, 516-524. [CrossRef]

22. Goodman, A. Implementing sustainability in service operations in Scandic hotels. Interfaces 2000, 30, $202-214$. [CrossRef]

23. Meade, B.; Pringle, J. Environmental management systems for Caribbean hotels and resorts: A case study of five properties in Jamaica. J. Qual. Assur. Hosp. Tour. 2001, 2, 149-159. [CrossRef]

24. Bohdanowicz, P.; Zientara, P.; Novotna, E. International hotel chains and environmental protection: An analysis of Hilton's we care! programme (Europe, 2006-2008). J. Sustain. Tour. 2011, 19, 797-816. [CrossRef]

25. Noone, B.M.; Kimes, S.E.; Mattila, A.S.; Wirtz, J. The effect of meal pace on customer satisfaction. Cornell Hotel Restaur. Adm. Q. 2007, 48, 231-244. [CrossRef]

26. Chan, W.W. Environmental measures for hotels' environmental management systems. Int. J. Contemp. Hosp. Manag. 2009, 21, 542-560. [CrossRef]

27. Robinot, E.; Giannelloni, J.L. Do hotels' "green" attributes contribute to customer satisfaction? J. Serv. Mark. 2010, 24, 157-169. [CrossRef]

28. Hsiao, T.; Chuang, C. Creating Shared Value through Implementing Green Practices for Star Hotels. Asia Pac. J. Tour. Res. 2016, 21, 678-696. [CrossRef]

29. Tesone, D.V. Development of a sustainable tourism hospitality human resources management module: A template for teaching sustainability across the curriculum. Hosp. Manag. 2004, 23, 207-237. [CrossRef]

30. Shin, I.; Hur, W.M.; Kang, S. Employees' Perceptions of Corporate Social Responsibility and Job Performance: A Sequential Mediation Model. Sustainability 2016, 8, 493. [CrossRef]

31. Biondi, V.; Iraldo, F.; Meredith, S. Achieving sustainability through environmental innovation: The role of SMEs. Int. J. Technol. Manag. 2002, 24, 612-626. [CrossRef]

32. Berkhout, F. Technological regimes, environmental performance and innovation systems: Tracing the links. In Towards Environmental Innovation Systems; Springer: Berlin/Heidelberg, Germany, 2005; pp. 57-80.

33. Segarra-Oña, M.D.V.; Peiró-Signes, A.; Albors-Garrigós, J.; Miret-Pastor, P. Impact of innovative practices in environmentally focused firms: Moderating factors. Int. J. Environ. Res. 2011, 5, 425-434.

34. Horbach, J.; Rammer, C.; Rennings, K. Determinants of eco-innovations by type of environmental impact-The role of regulatory push/pull, technology push and market pull. Ecol. Econ. 2012, 78, 112-122. [CrossRef] 
35. Jänicke, M.; Jacob, K. Ecological modernisation and the creation of lead markets. In Towards Environmental Innovation Systems; Springer: Berlin/Heidelberg, Germany, 2005; pp. 175-193.

36. Del Río González, P. Analysing the factors influencing clean technology adoption: A study of the Spanish pulp and paper industry. Bus. Strateg. Environ. 2005, 14, 20-37. [CrossRef]

37. Popp, D. International innovation and diffusion of air pollution control technologies: The effects of $\mathrm{NO}_{X}$ and $\mathrm{SO}_{2}$ regulation in the US, Japan, and Germany. J. Environ. Econ. Manag. 2006, 51, 46-71. [CrossRef]

38. Bossle, M.B.; de Barcellos, M.D.; Vieira, L.M.; Sauvée, L. The drivers for adoption of eco-innovation. J. Clean. Prod. 2016, 113, 861-872. [CrossRef]

39. Muscio, A.; Nardone, G.; Stasi, A. Drivers of eco-innovation in the wine industry. Presented at DRUID15, Rome, Italy, 15-17 June 2015.

40. Del Val Segarra-Oña, M.; Peiro-Signes, Á. Eco-innovation determinants in service industries. Dir. Org. 2013, 50, 5-16.

41. Triguero, A.; Moreno-Mondéjar, L.; Davia, M.A. Drivers of different types of eco-innovation in European SMEs. Ecol. Econ. 2013, 92, 25-33. [CrossRef]

42. Chen, C.J.; Huang, J.W. Strategic human resource practices and innovation performance-The mediating role of knowledge management capacity. J. Bus. Res. 2009, 62, 104-114. [CrossRef]

43. Cainelli, G.; Mazzanti, M.; Zoboli, R. Environmental innovations, complementarity and local/global cooperation: Evidence from North-East Italian industry. Int. J. Technol. Policy Manag. 2011, 11, 328-368. [CrossRef]

44. Santolaria, M.; Oliver-Solà, J.; Gasol, C.M.; Morales-Pinzón, T.; Rieradevall, J. Eco-design in innovation driven companies: Perception, predictions and the main drivers of integration. The Spanish example. J. Clean. Prod. 2011, 19, 1315-1323. [CrossRef]

45. Carrillo-Hermosilla, J.; Del Río, P.; Könnölä, T. Diversity of eco-innovations: Reflections from selected case studies. J. Clean. Prod. 2010, 18, 1073-1083. [CrossRef]

46. The Organisation for Economic Co-operation and Development (OECD). Oslo Manual. Guidelines for Collecting and Interpreting Innovation Data; OECD Publishing: Paris, France, 2005.

47. Sezen, B.; Çankaya, S.Y. Effects of green manufacturing and eco-innovation on sustainability performance. Proc. Soc. Behav. Sci. 2013, 99, 154-163. [CrossRef]

48. Dong, Y.; Wang, X.; Jin, J.; Qiao, Y.; Shi, L. Effects of eco-innovation typology on its performance: Empirical evidence from Chinese enterprises. J. Eng. Technol. Manag. 2014, 34, 78-98. [CrossRef]

49. Teng, C.C.; Chang, J.H. Effects of temporal distance and related strategies on enhancing customer participation intention for hotel eco-friendly programs. Int. J. Hosp. Manag. 2014, 40, 92-99. [CrossRef]

50. Rodgers, S. Innovation in food service technology and its strategic role. Int. J. Hosp. Manag. 2007, 26, 899-912. [CrossRef]

51. Bastic, M.; Gojic, S. Measurement scale for eco-component of hotel service quality. Int. J. Hosp. Manag. 2012, 31, 1012-1020. [CrossRef]

52. Horng, J.S.; Chou, S.F.; Liu, C.H.; Tsai, C.Y. Creativity, aesthetics and eco-friendliness: A physical dining environment design synthetic assessment model of innovative restaurants. Tour. Manag. 2013, 36, 15-25. [CrossRef]

53. Karakaya, E.; Hidalgo, A.; Nuur, C. Diffusion of eco-innovations: A review. Renew. Sustain. Energ. Rev. 2014, 33, 392-399. [CrossRef]

54. Ceulemans, K.; Lozano, R.; Alonso-Almeida, M.M. Sustainability Reporting in Higher Education: Interconnecting the Reporting Process and Organisational Change Management for Sustainability. Sustainability 2015, 7, 8881-8903. [CrossRef]

55. Alonso-Almeida, M.; Llach, J.; Marimon, F. A closer look at the 'Global Reporting Initiative' sustainability reporting as a tool to implement environmental and social policies: A worldwide sector analysis. Corp. Soc. Responsib. Environ. Manag. 2014, 21, 318-335. [CrossRef]

56. Marimon, F.; Alonso-Almeida, M.M.; Rodríguez, M.P.; Alejandro, K.A.C. The worldwide diffusion of the global reporting initiative: What is the point? J. Clean. Prod. 2012, 33, 132-144. [CrossRef]

57. Ronde, P. Delphi analysis of national specificities in selected innovative areas in Germany and France. Technol. Forecast. Soc. Chang. 2003, 70, 419-448. [CrossRef] 
58. Hoejmose, S.; Brammer, S.; Millington, A. An empirical examination of the relationship between business strategy and socially responsible supply chain management. Int. J. Oper. Prod. Manag. 2013, 33, 589-621. [CrossRef]

59. European Commission, Lisbon Strategy Evaluation Document. Available online: http://ec.europa.eu/ europe2020/pdf/lisbon_strategy_evaluation_en.pdf (accessed on 3 September 2016).

60. Hjalager, A.M. 100 innovations that transformed tourism. J. Travel Res. 2015, 54, 3-21. [CrossRef]

(C) 2016 by the authors; licensee MDPI, Basel, Switzerland. This article is an open access article distributed under the terms and conditions of the Creative Commons Attribution (CC-BY) license (http:/ / creativecommons.org/licenses/by/4.0/). 